\title{
Faculty members and academic librarians: Distinctive differences
}

\author{
By Rebecca Kellogg \\ Associate Dean of the College of Arts \& Sciences \\ University of Arizona
}

\section{How librarians appear to administrators and teaching faculty.}

\begin{abstract}
M $y$ administrative views of academic librarians are biased by the fact that I am a librarian. I am also a bureaucrat, an administrator, otherwise known as one of "them." I am not a faculty member as such is defined by faculty members. And perhaps because of experience within these roles, I found this speech difficult to write. These days, as I talk with academic librarians, I want very much to discuss what librarians can do to assist their institutions in improving undergraduate education. I don't want to talk about faculty status or about the lack of money. I want to talk about why librarians should take responsibility for teaching undergraduates the methodology that underlies the critical thinking which is a part of any and all learning processes. I don't want to talk about why faculty don't consider librarians "peers."

I want to talk about librarians participating as members of the academic community in a larger role than faculty members could ever attain. I don't want to talk about the fact that I now routinely skip all articles about how faculty status of librarians is viewed by someone somewhere. I would like to talk about how politically to get what you want from the administration. But if faculty status has to come first, then I am out in the cold. I would much prefer to be able to suggest specific, practical services which could make academic librarians more important to the institution. If ser-
\end{abstract}

vice is not as important as titles to academic librarians, then I can't talk with you. I want to talk about quality-not about rank.

However - after various drafts on topics concerning undergraduate education, institutional missions, and the role of librarians within the academic community, I find myself drawn back to the problem of status. So, in order to be able to go on later to these other topics and probably to clear out my system, I will share with you my views on how faculty members and academic librarians are perceived differently by administrators. My words will not resolve this debate, but perhaps I can provide a perspective not frequently found: that of an academic administrator who is also a librarian.

\section{Faculty members: The discipline}

To be a member of the faculty is to have been admitted into a closed, select circle where, even for those within it, not everyone or every discipline is equal. And it is crucial to any discussion of faculty members to understand that within most academic institutions the word "faculty" is inexorably linked with the word "discipline."

A quote from Ernest Boyer's College: The Undergraduate Experience in America: "Whereas 26 percent of faculty feel their 'college' is 'very important' to them, 76 percent rate their 'academic disci- 
pline' as 'very important.","

Those faculty members who hold most strongly to the concept of "the discipline" are those possessing the Ph.D. The majority of them were lowerdivision undergraduates when they had their last required exposure to a body of work outside their disciplines. Once into upper-division courses and definitely by the end of graduate school, they had become immersed in the study of an increasingly narrow area of disciplinary specialization. As graduate students, they labored under faculty members within the same or an even smaller area of disciplinary study. Should one's major advisor move to another institution, the student moved also-as indeed she would be expected to do.

Such faculty have been through the war, and surviving a doctoral program is akin to having engaged in boot camp, trench warfare, and hand-tohand combat. One false move and your advisor may well shoot you dead; some don't survive.

Now armed, however, with the Ph.D, the prospective faculty member must find a position. It must be a tenure track one, since living on a nontenure track for more than one or two years assures you of almost never being hired into a tenure-track position: instant and permanent second-class status. Unless your specialization is in great demand or you are considered a "target of opportunity" (which means you are to fill a minority or female designated position), you must somehow convince prospective colleagues that you are (a) brilliant in your field but (b) not brilliant enough to be a threat to them. After having been hired, you may teach the basic departmental courses in addition to perhaps one in your own disciplinary area. You will also have to carry out research of such significance that the writing you do will be published. And as a new faculty member, you will have to serve on various committees on which no tenured faculty member would want to spend the time. While you may have a teaching load of 12 hours a week, you will spend almost twice that in class preparation, "the marking and evaluation of assignments, record keeping, and, of course, time devoted to private consultation with students." ${ }^{2}$ Of a 40 -hour week, you have now filled up 36 and there is still research to work on, write up, revise and get published. Once tenure is gained, many a faculty member begins to spend significant amounts of time doing whatever she wishes. Outside of teaching schedules, one's time is more one's own. And most of that time is spent on research and publication directly related to the discipline, especially one's now fairly well-established niche within it.

\section{Faculty members: Research}

Carrying out research within most disciplines

${ }^{1}$ Ernest Boyer, College: The Undergraduate Experience in America (New York: Harper and Row, 1987), 236.

${ }^{2}$ Ibid., 121. means advancing knowledge. Depending upon one's discipline, research may be a solitary endeavor or require the establishment and continuance of both a research team and an appropriate laboratory facility. Depending upon a faculty member's research reputation, she may or may not be the recipient of sabbaticals, leaves, grant monies, reduced teaching loads, minimal or nonexistent committee assignments, promotion, and honors and awards from peers within and outside the institution. Research is carried on at any and at all hours; as a fundamental thinking process it is not confined to an 8 to 5 Monday through Friday schedule. The fruits of a faculty member's research may never be seen by others outside the research group as experiments fail and theories are disproved. Or the work may mature in totally unanticipated ways - resulting in disciplinary advancements hailed by peers. Or the fruits may be appreciated only by the faculty member, who understands now more clearly than ever before the essential nature of her or his work. For many outstanding faculty members, research and its publishable results also mean the administration will leave you alone-so you can pursue the exotic headiness of work within the discipline and the advancement of knowledge which comes from it. No one knows what you know to the degree that you know it, and no one can convey it as you can. They do not literally live it as you do; they do not own it as you do. And woe be to the person who treads on what you know to be yours.

As a summary of these comments on faculty research, a quote from William Dickinson, head of the Geosciences Department at the University of Arizona:

"In my heart, I think that the discovery inherent in research and the transmission inherent in teaching are truly two sides of the same coin. Teacher and student are both engaged in the same kind of inquiry, and the habits of hypothesis and analysis embodied in what we call research are essential to the process... In my mind research is a key source of vitality and a prime touchstone with reality. We all need it in some measure to embrace the future, which is always unpredictable and different from what we know now."3

\section{Faculty members: Teaching}

However, the faculty members most appreciated by administrators are those who both carry out research and teach courses. Here "teaching" is defined as the formal, structured imparting of knowledge gained from study within or related to one's discipline, and conveyed to students through academic course content. Much has been made about the relationship of teaching and research. Outstanding faculty members, such as Bill Dickin-

3“"The Spirit of Inquiry," an insert to Lo Que Pasa, the University of Arizona faculty/staff newsletter, March 23, 1987, p.4. 
son, do indeed come full circle by conducting research in order to advance their field, and by taking what has been gained from that research "back into the classroom." However, teaching is carried out through the systematic presentation of the knowledge pertinent to the subject of the course. The presentation is conveyed over a fixed period of time. And the content is comprised of those ele-

\section{A doctoral program is akin}

\section{to boot camp or trench}

\section{warfare.}

ments which the instructor has determined are essential for a student's mastery of the course topic. To develop the course, the relationship of this one to others within the department or program is determined. The material which must be presented is identified through review of the literature and of the research both directly and tangentially related to the topic. The arrangement of the course elements is established so that cumulative learning can be achieved. The syllabus, each assignment, each examination question, and the grading procedure are created. The course description is reviewed by the departmental curriculum committee, discussed by the full departmental faculty, and (if approved) submitted to the other college and institutional curricular committees. Assuming no challenges are lodged against it by other departments or colleges, the course is added to the institution's curriculum and teaching is authorized. This process from the idea to the first term of teaching the course routinely takes one to two semesters.

Administrators protect faculty members, especially those who are outstanding both in their research and their teaching. By so doing, such faculty are kept happy, which usually means they stay at the institution. For the reputation of the institution is built upon the reputations of eminent faculty members and the departments, programs, and laboratories with which they are associated. It is to study under them that outstanding students come; it is because of their work that agencies fund grants; it is because of the resulting reputation of the institution that chairs are endowed, and governing bodies support increases in academic budgets. It may seem crass to say so, but such faculty members are the geese who lay the golden eggs.

\section{Administrators}

Consider now the academic administrator. In almost all cases, that person is simply a faculty member who has taken on bureaucratic responsibilities. This administrator with responsibility for other people, units, and services may have received no training outside of the discipline, the classroom, and the research facility.

As a new administrator you would find that of greater difficultly than the learning of new work habits would be the realization that you are no longer considered "faculty" by most of the members of that closed, select circle. To be referred to as a "former colleague" by people who literally yesterday considered you their peer is a recurring bad memory. Even though you as an academic administrator will invariably identify yourself as "Susan Smith, professor of X" before saying "and dean (or vice president or whatever) of $Y$," it is clear that you have strayed from the Yellow Brick Roadperhaps even crossing over the River of No Return. You, however, continue to see yourself as a faculty member-holding on to your "faculty-ness."

\section{Librarians}

Now into this mixture let us add librarians. First of all, academic administrators and most faculty members generally do not think about librarians; they think about libraries. A quote from an article entitled, "Faculty Perceptions of Librarians at the University of Manitoba:" "It was remarkable that many [faculty] participants [in the study] seem to consider the library simply as an institution, with little regard for the people who are instrumental in its functioning." Given what I have just said about faculty members, this should not have been at all surprising. For even more than thinking of a place called "the library," faculty members and administrators think about library collections. Academic administrators think about those collections in terms of (1) their own disciplines and (2) the needs of students-their own and those of students in general. If a librarian is "thought about," it will usually be the head of the library, for that is the individual with whom the administrator will have the most contact. An administrator's contact with other librarians is restricted to those who infrequently serve on appointed or elected non-library related committees.

When asked about librarians, administrators tend to draw upon their graduate years or faculty experience for descriptive answers. Scientists will have had few interactions with librarians due to the laboratory nature of their work. Humanists will have had a much greater number of interactions, since the library essentially is their laboratory. In the case of administrators who have had some type of regular, prior contact with librarians, that contact would have been greatest with reference librarians and perhaps least with catalogers.

${ }^{4}$ Gaby Divay, Ada M. Ducas, and Nicole Michaud-Oystryk, "Faculty Perceptions of Librarians at the University of Manitoba," College $b$ Research Libraries 48 (January 1987):33. 
Administrators do not know enough about our discipline to realize that there are theoretical and applied differences within the field of librarianship. Administrators describe librarians as professionals-meaning people who are highly skilled in putting the knowledge of their field into practice. But the very "practice" of librarianship makes it the application of knowledge and not the advancement of knowledge.

Pauline Wilson has written that "it is not that teachers and professors will not recognize librarians as teachers. Rather, it is that they cannot. There is nothing visible with which a connection can be made to permit or produce recognition." 5 Although I think her statement is a bit extreme, it is absolutely true that at most institutions, teaching students across the reference desk or in a one- or two-shot BI session will never serve to open the doors of membership into the professorate. It will never be understood as "teaching" by administrators for whom that activity is a formal, structured process in which knowledge is conveyed through the academic content of a course.

Most administrators believe that the work of the librarian is to determine what materials are needed in order to support the educational and intellectual work of faculty members and students, and to acquire and make that material available. As Princeton's President Bowen has said: "To bring students, faculty and books together in ways that...encourage learning, intensive scholarship, and casual browsing." 6

Administrators do not see librarianship, nor library practice, as "an interdisciplinary field concerned with all phases of the information transfer process"- a description provided by Charles Davis and James Rush. ${ }^{7}$ Nor do they understand it to entail "an in-depth understanding of the graphic record as a structure, an entity." And if you asked them about the relationship between librarianship and other social and behavioral sciences, they would not necessarily understand that librarianship is an extension of the same basic theories which underlie those particular sciences.

Administrators believe that, as I noted before, academic librarians are professionals; that they are essential members of the academic community; that, without the skills and support of librarians, a significant amount of teaching and research would never occur. Many administrators also believe that although academic librarians do not do the same

${ }^{5}$ Pauline Wilson, "Librarians as Teachers: The Study of an Organizational Fiction," Library Quarterly 57 (April 1979):154.

6“"The Princeton Library," Princeton Alumni Weekly, April 23, 1986, p.8.

'Charles H. Davis and James E. Rush, "Library and Information Science Research," in ALA World Encyclopedia of Library and Information Services, 2 d ed. (Chicago: American Library Association, 1986), 460-62.

${ }^{8}$ Wilson, "Librarians as Teachers," 155. teaching and research work as that of faculty members, it is essential that librarians receive many of the same benefits and supports as those provided to faculty members.

Should academic librarians undertake to work actively on institutionally defined problems, administrators could come to believe that it is the responsibility of the academic librarian to continu-

\section{Critical thinking is a}

\section{natural product of graduate} work in librarianship.

ously monitor the curriculum in order to assure that the library's collection does indeed respond to the various changes which regularly sweep over that curriculum. Also, that it is the responsibility of academic librarians to know in some depth both the teaching expectations and the research activities of the outstanding faculty on their campuses.

Administrators could be fairly easily convinced that librarianship is a discipline in which one is being trained extensively in methodology, which is a "body of methods, procedures, working concepts, rules and postulates employed by a science, art or discipline." $"$ There is no reason why administrators should not understand that learning to catalog is learning not only a system of rules and the arrangements of those rules, but the appropriate application of them to a specific entry or descriptive end. Or that reference work is the choice and application of an identified methodology which results in a series of "yes/no" statements which delimit a field of sources or pieces of information down to a single result. Or that critical thinking is the natural byproduct of graduate work in librarianship, just as it is of graduate work in any field: by this I mean that skillful judgment as to the truth or merits of a chosen methodology is the basic tool used for the successful resolution of a problem at hand. But are these the ways and the words chosen by most academic librarians when defining what they do?

This is my final pitch: administrators could know all these things about librarianship and thus about the value of academic librarians to the greater good of the institution. However, they do not know and, for any administrator to change her view, librarians must see their work and their status through these types of words, descriptions and concomitant actions. It is the activities of the academic librarian which will confirm or alter the

\footnotetext{
${ }^{9}$ Webster's Third New International Dictionary, s.v. "methodology."
} 
view of the administrator; the setting aside of the question of status in order to take on the larger, more fundamental, and infinitely more important question of how the unique knowledge of academic librarians should be identified and used by the institution in support of institutional missions, concerns, and needs. Only when shifts in administrative-and faculty-perceptions have occurred will academic librarians be accorded the high status they will be seen to truly deserve.

Editor's Note: This article is based on a speech given before the Wisconsin Association of Academic Librarians at the WAAL Spring Conference, April 24, 1987, and published here as a follow-up to the author's "Beliefs and Realities," C\&RL News, September 1986, pp. 492-96.

\title{
Academic library funding and
}

\section{professional ethics}

\author{
By J. Richard Madaus \\ Dean of Library and Learning Resources \\ Northeastern State University
}

\section{$6 \%$ library funding as an employment consideration.}

T ough economic times and/or budget problems in academic libraries are common experiences in our profession. An academic library represents considerable fiscal commitment (even poorly funded) for any higher education institution. The ACRL "Standards for College Libraries" clearly state, "the library's appropriation shall be six percent of the total institutional budget for educational and general purposes." Should we, as professionals, treat this six percent level as a goal or a minimum for basic quality services?

How do we (or do we at all?) consider the basic budget construct of a library as part of our paradigm of acceptable working conditions? Ethics, by definition, deal with principles for conduct. Logically, there should be a place in the interpretation of our professional ethics for a review of our institution as it provides us with the basic resources to carry out our profession. Funding is, of course, the key to these resources.
Professional ethics should, in my opinion, extend to the basic level of the acceptance or rejection of the conditions and circumstances under which we as professionals will allow ourselves to work.

Just how do we really act about our working conditions during good economic times (or bad times), and does it affect our funding? I am firmly convinced that it does. I am also firmly convinced that in our efforts to keep service going in tough times we may dilute our efforts simply too much. I believe this has, and will continue to keep academic libraries underfunded unless we make significant change. This is not to say we don't do very good jobs with what resources we have. I think we do. Perhaps we have done so well, with so little, for so long that now it has become expected of us. Scraping by (at $4 \%-6 \%$ of E\&G-education and general-funding levels) has become definitially part of our job.

We will keep the library open at all costs, even if 